\title{
The Use of PhET Simulations in Teaching Modality in High Schools in Albania before and during COVID 19-Pandemic
}

\author{
R. O. Zeqirllari, K. Peqini, and D. Xhako
}

\section{ABSTRACT}

In this paper, we present a survey - based study regarding the use of PhET simulations in the teaching modality in high schools of Albania before and during COVID-19. We are mainly interested in teachers' attitudes on Physics PhET simulations and their impact on the high school students' performance. This study was performed in 125 high schools, in 10 different cities of Albania. For this, we have performed a survey composed of 25 questions for 180 teachers, of which $72 \%$ working in public schools. The results show that most of the teachers, have information about PhET simulations but during the classical face to face teaching, the usage percentage was about $41 \%$. While during online classes the use of PhET simulations increased. The results show that the interest of students toward physics increases when PhET simulations are used. What can be understood easily is the fact that even PhET simulations are very useful in understanding physics, both in face to face and online teaching, the teachers in Albania seems not to be so "friendly" with them. Albanian teachers seem to be more attractive by the traditional teaching.

Keywords: COVID-19 Pandemic, High-schools, PhET Simulations, Teachers

Published Online: December 21, 2021

ISSN: $2736-4534$

DOI :10.24018/ejedu.2021.2.6.229

\section{R. O. Zeqirllari}

University of Tirana, Faculty of Natural Sciences, Department of Physics

Faculty of Natural Sciences, Bvd "Zogu I", Tirana, Albania

(e - mail: rudina.zeqirllar@fshn.edu.al ) K. Peqini

University of Tirana, Faculty of Natural Sciences, Department of Physics Faculty of Natural Sciences, Bvd "Zogu

I", Tirana, Albania

(e-mail: klaudio.peqini@ ${ }_{\text {fshn.edu.al) }}$

D. Xhako

Polytechnic University of Tirana, Department of Physics Engineering

St. "Muhamet Gjollesha", Tirana, Albania

(e-mail:dafinaxhako@yahoo.com)

*Corresponding Author

\section{INTRODUCTION}

In the last two years, the world is facing with a not normal situation: the COVID - 19 pandemic (WHO, 2020). Almost all the countries passed a lockdown period of time, full with restrictions. Due to restrictions on activities in the education sector, teaching and learning activities were carried out at home, and online learning became a new trend in all the world. The same happened in Albania, and the first months, from March to June 2020 were the most difficult regarding the distance/online teaching. The teachers have the duty and responsibility to find new methods of teaching modalities, adaptable for this new situation. In the distance learning, the interaction between teachers and students happens virtually, using tools or technology such as computers or cell phones. Both, teachers and students have to adapt with this situation. (Paudel, 2021; Urokova, 2020). Sciences' teachers were the ones who had more difficulties in this process. The lack of face to face reactions and especially of laboratories were two of the main reasons responsible for what we mentioned above. Physics was one of the most effected subjects. This because physics is a way to understand how this nature works, it's not just equations. That's why labs are very important. During online teaching, virtual laboratories have to be implemented in order to make clear the lessons' topics. One of the most useful tools for virtual laboratories and simulations is PhET simulation media (Wieman et al., 2008). PhET Interactive Simulations, a project at the University of Colorado Boulder, was founded in 2002 by Nobel Laureate Carl Wieman. PhET began with Wieman's vision to improve the way science is taught and learned. The acronym "PhET" initially stood for "Physics Education Technology," but soon PhET was used even for other disciplines, such as: chemistry, biology, earth science, and mathematics. The team changes over time and the current director of PhET is Dr. Katherine Perkins (Perkins et al., 2006; Guttenplan, 2011; Hensberry et al., 2013).

$\mathrm{PhET}$ Interactive Simulations implement research-based practices on teaching in order to increase the learning of science concepts. The simulations are designed to be simple so in order to be used as lecture demonstrations, laboratories, or homework. They use an environment where students can learn through exploration and where science ideas are connected to real-world life phenomena.

The PhET team performs education research on their simulations. They have shown in their research that when students explore simulations in addition to traditional labs, student concept understanding improves (Wieman et al., 2008). The idea of our study was to see how virtual laboratories and simulations in physics, especially PhET simulations are implemented in the teaching modalities, in 
both cases: in person and online teaching, in the high schools of Albania.

\section{MethodolOGY}

The study was conducted with 180 teachers (ages from 24 - 60 years) working in 125 high - schools, 20 of them nonpublic schools, in seven important cities of Albania: Tirana, Durrës, Korca, Fier, Vlora, Shkodra and Kukës. For the teachers we prepared a survey with 25 questions regarding the use of PhET simulations before and during the online teaching. Some of the questions for the teachers were: Do you use PhET simulations during the online teaching? Do you have previous experience with PhET simulations in the face to face teaching? Did you have difficulties in the beginning of the online teaching with PhET simulations? How useful are PhET simulations for the students? Can it substitute the laboratories in person? Where is more effective the use of PhET simulations: in person or online? How PhET simultations help in the uderstanding of the students? We prepared an online survey in Google forms for the teachers, shared in LinkedIn, in a public group on Facebook, "The platform "Mesuesi i fizikes online"(Online Physics teachers)", and directly to schools.

We collected data from March 2021 to June 2021 and then analysed the results. All the analise is more qualitative, in order to have an idea of what the impact of using PhET simulations was.

\section{RESULTS}

After we collect the data, we made a simple analysis of the results for the questions of the survey. Some of the most important questions and the related results are presented in the figures below. The first figures, from 1 to 8 , present results of the questions regarding teachers' attitude regarding PhET simulations use, while figures from 9 to 12 present results regarding students' performance and its connection with PhET simulations. We choose to present all the results in terms of percentages in order to create a better idea of where and how the situations was.

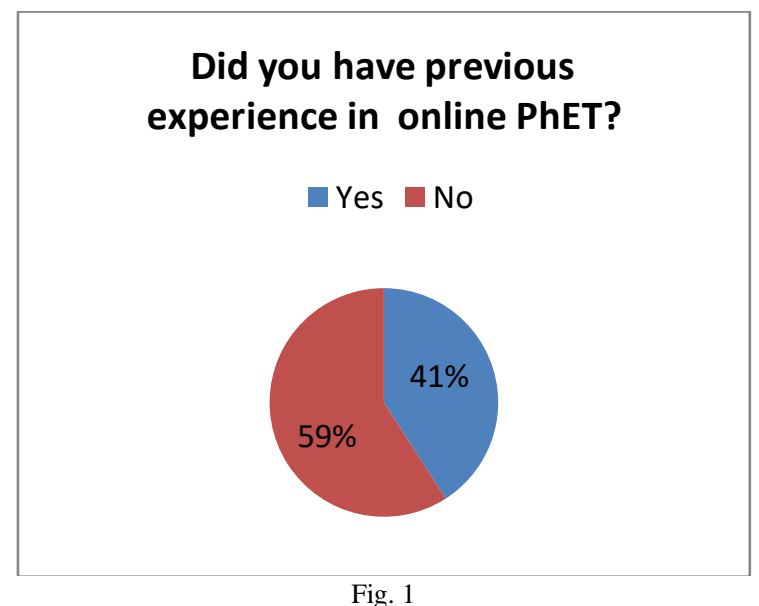

Fig. 1

\section{Did you had difficulties in the operation of the online PhET at the begining of the pandemy?}

Yes No Partially

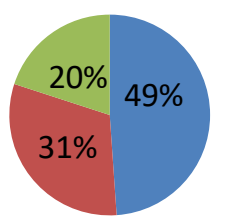

Fig. 2

\section{Do you think that PhET simulations can be used in online teching?}

$$
\square \text { Yes } \square \text { No }
$$

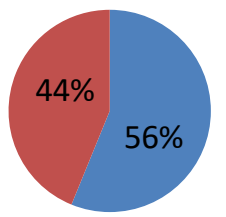

Fig. 3

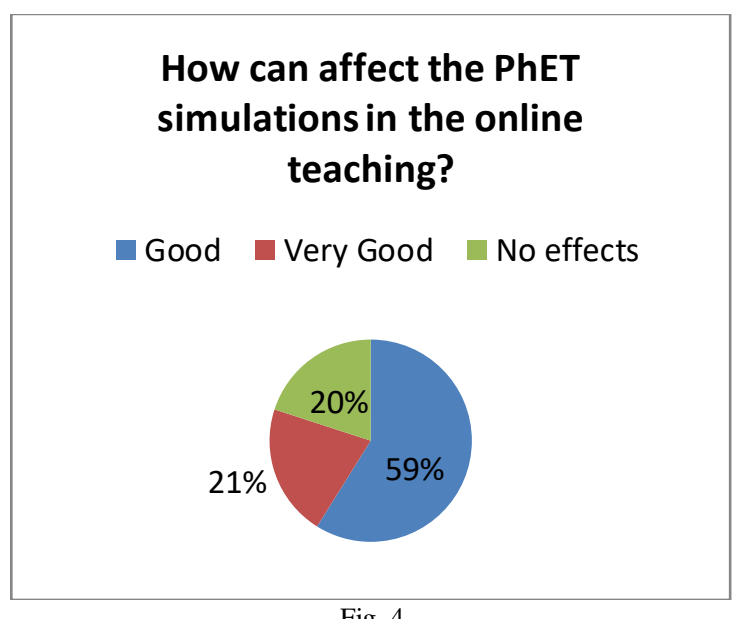

Fig. 4 


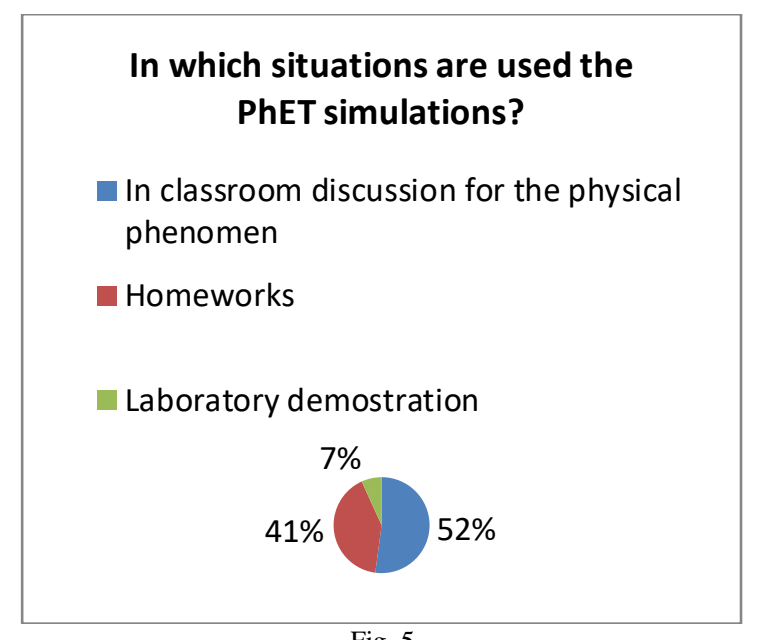

Fig. 5

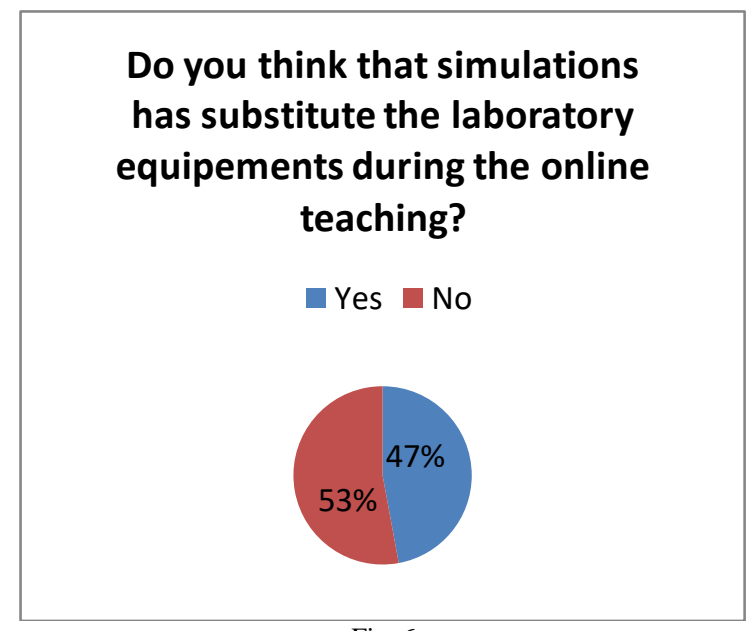

Fig. 6

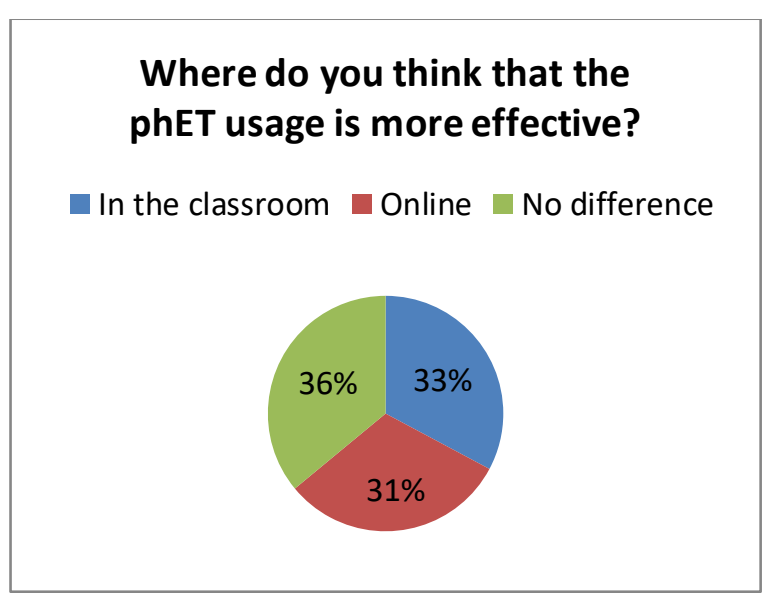

Fig. 7
The lessions are more effective when teachers use:

$\square$ PhET $\square$ Tradicional methods $\square$ No difference

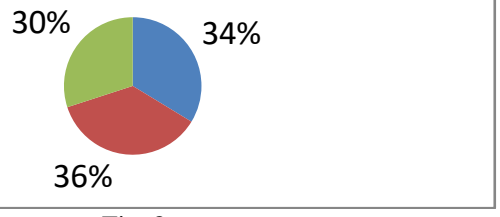

Fig. 8

During the online lessions when you use the simulations the activity of the students is:

Low $\square$ Medium $\square$ High

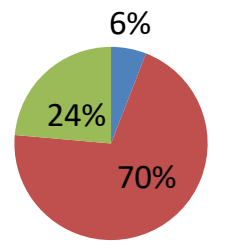

Fig. 9

When do you have more interes from the students during the PhET simulations or during the lessions?

When I explain lessions

- When using PhET simulations

Both of them

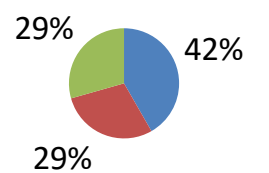

$29 \%$

Fig. 10 


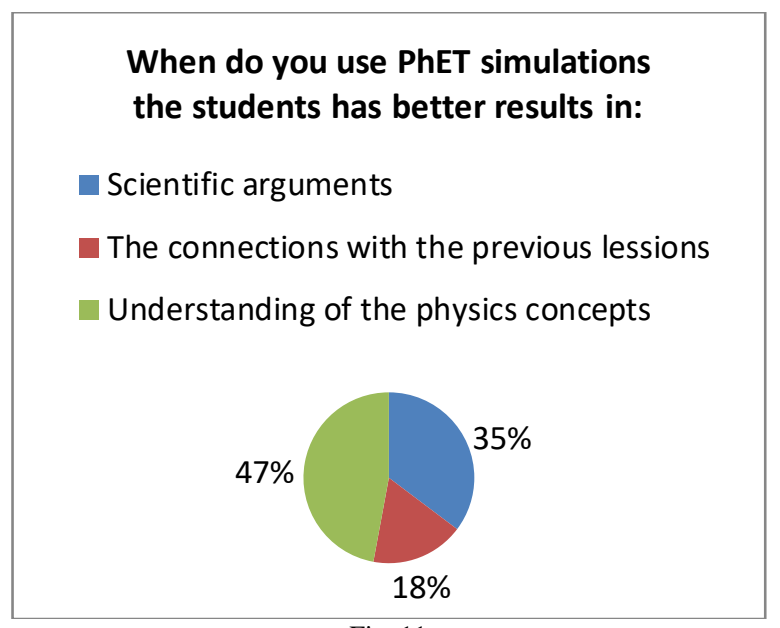

Fig. 11

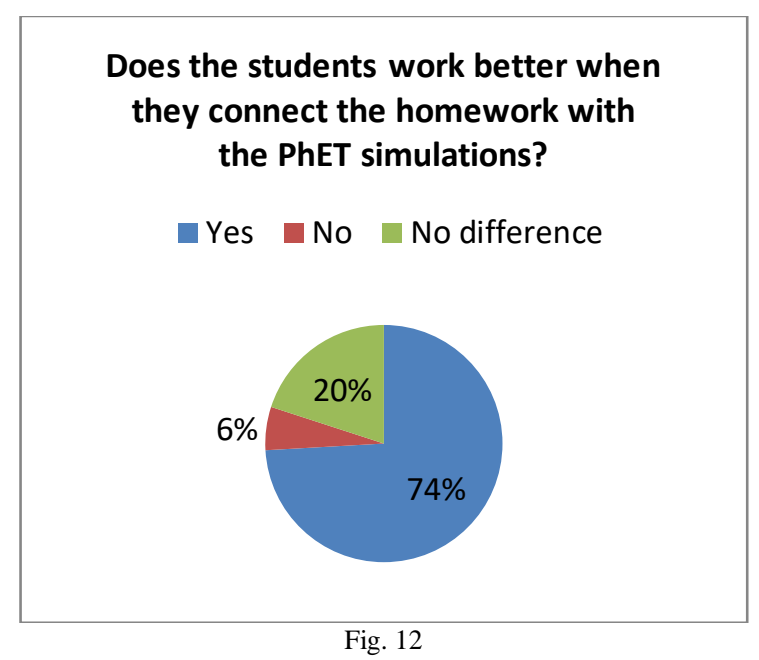

\section{CONCLUSIONS}

As can be seen by the results, high school teachers In Albania have used PhET - simulations even before the online teaching, but just as demonstrations, and adding them to the traditional teaching methods. Interesting was the fact, that most of the teachers who used PhET - simulations during the face to face teaching, work on nonpublic schools. This because this schools have all the infrastructure to support this kind of teaching modality. What we saw by the results, was the fact that the usage percentage of Physics PhET simulations increased during the pandemic online teaching. It can be considered quite normal, because teachers have the possibilities to have contact with computers and internet during the lessons, differently from the face to face case in public schools. Also, they have to find methods to make more attractive and effective the lessons. As we can see from the results, most of the teachers initially had problems using PhET in the conditions of the pandemic situation, when most of the teaching elements had to be reframed. Anyway, besides the increased usage percentage of PhET simulations, the teachers in Albania, believe that the simulations can't substitute the laboratories.

Regarding the students' performance, the teachers noticed that the students like the use of simulations during the lesson, in classroom or online. Comparing to the traditional lessons during the online learning, the teachers noticed that the activity of the students, their concentration and the homework performance increased when PhET simulations are used. So, they confirm that the use of Physics PhET simulations affect for good the online teaching. Besides this, an interesting fact is that for the teachers there is no difference of where is better to use PhET, in classroom or online and most of them seem to be convinced that the traditional method of teaching is the best one.

\section{ACKNOWLEDGMENT}

This work would have not been possible without the help of all the high school's teachers who found time to answer all the questions and to share their thoughts with us as well as to share this survey with others. A special acknowledgment goes to our graduate student, Shpresa Balliu, who helped us with the survey.

\section{CONFLICT OF INTEREST}

Authors declare that they do not have any conflict of interest.

\section{REFERENCES}

Adams, W.K, et al. (2008). A study of educational simulations part I Engagement and learning. Journal of Interactive Learning Research, 19(3), 397-419.

Bell, R. B., \& Smetana, L. K. (2008). Using computer simulations to enhance science teaching and learning, National Science Teachers Association, 3, 23-32.

Bryan, J. (2006), Technology for Physics Instruction. Contemporary Issues in Technology and Teacher Education, 6(2), 230-245.

Fegert, J.M., et al. (2020), Challenges and burden of the Coronavirus 2019 (COVID-19) pandemic for child and adolescent mental health: a narrative review to highlight clinical and research needs in the acute phase and the long return to normality. Child Adolesc Psychiatry Ment Health, 14, 20 https://doi.org/10.1186/s13034-020-00329-3

Guttenplan, D.D. (2011). "Web Tutors Become Stars Far from Classroom". New York Times.

Hensberry, K. K. R, et al. (2013), PhET Interactive Simulations: New Tools to Achieve Common Core Mathematics Standards, Common Core Mathematics Standards and Implementing Digital Technologies , 147-167

Paudel, P. (2021). Online education: Benefits, challenges and strategies during and after COVID-19 in higher education. International Journal on Studies in Education, 3(2), 70-85.

Perkins, K. et al. (2006). PhET: Interactive Simulations for Teaching and Learning Physics. The Physics Teacher, 44(1), 18

Simons, N.E., Menzies, B., Matthews, M. A. (2001). Short Course in Soil and Rock Slope Engineering. London: Thomas Telford Publishing.

United Nations (2020). Policy Brief: Education during COVID-19 and beyond.

Urokova, S. (2020). Advantages and disadvantages of online education,. ISJ Theoretical \& Applied Science, 9(89), 34-37.

Wieman, C. et al. (2008). PhET Research: Simulations that Enhance Learning. Science, 322 (5902), 682-3.

World Health Organization (2020). "WHO Coronavirus Disease (COVID19) Dashboard," World Health Organization.

https://www.facebook.com/groups/305020239837378/

Zimmer, E., (2012), Inquiry-based Lessons and PhET Simulations - A Great Match for Middle School Classrooms, Presented at the Society for Information Technology \& Teacher Education International Conference 